\title{
Preharvest treatment with 1-aminoethoxyvinylglycine and gibberellin on the quality and physiology of cashew peduncles
}

\author{
Kellina Oliveira de Souza(1), Cícera Vanuza Xavier(1), Mônica Maria de Almeida Lopes ${ }^{(2)}$, \\ Carlos Farley Herbster Moura ${ }^{(3)}$, Ebenezer Oliveira Silva ${ }^{(3)}$, \\ Jesus Fernando Ayala-Zavala ${ }^{(4)}$ and Maria Raquel Alcântara de Miranda(2)
}

\begin{abstract}
(1)Universidade Federal do Ceará (UFC), Programa de Pós-graduação em Fitotecnia, Avenida Mister Hull, no 2.297, Campus do Pici, CEP 60356-001 Fortaleza, CE, Brazil. E-mail: kellina@gmail.com, vanuzaxavier@bol.com.br (2)Universidade Federal do Ceará (UFC), Departamento de Bioquímica e Biologia Molecular, Avenida Engenheiro Humberto Monte, s/no, Campus do Pici, CEP 60440-900 Fortaleza, CE, Brazil. E-mail: monicalopes5@hotmail.com, raquelamiranda@gmail.com ${ }^{(3)}$ Embrapa Agroindústria Tropical, Rua Dra. Sara Mesquita, no 2.270, Planalto do Pici, CEP 60511-110 Fortaleza, CE, Brazil. E-mail: farley.moura@embrapa.br, ebenezer.silva@embrapa.br ${ }^{(4)}$ Centro de Investigación en Alimentación y Desarrollo, A.C., Carretera a la Victoria, Km 0.6., Hermosillo, C.P. 83304 Sonora, Mexico. E-mail: jayala@ciad.mx
\end{abstract}

\begin{abstract}
The objective of this work was to evaluate the effects of the preharvest treatment with gibberellic acid $\left(\mathrm{GA}_{3}\right)$ and aminoethoxyvinylglycine (AVG) on the quality and physiological attributes of ripe 'CCP 76 ' cashew (Anacardium occidentale) peduncles at different developmental stages. Sprays of $180 \mathrm{mg} \mathrm{L}^{-1} \mathrm{GA}_{3}$ and $180 \mathrm{mg}$ $\mathrm{L}^{-1}$ AVG were applied, combined and isolated, at 34, 40, and 44 days after anthesis (DAA), and peduncles were harvested ripe at $46 \mathrm{DAA}$ and evaluated for physical and physiological variables. The treatment with $\mathrm{GA}_{3}$ resulted in firmer peduncles with a greater apical diameter, but did not affect the physiological variables activity of the pectin methylesterase and polygalacturonase cell wall enzymes and degree of lipid peroxidation of the biological membranes, nor the physical attributes total mass (peduncles and nut) and nut size. At early developmental stages (34 DAA), $\mathrm{GA}_{3}$ increased the activity of the antioxidant enzymes superoxide dismutase and catalase, and, at later stages (40 DAA), promoted polyphenol and carotenoid accumulation. The application of AVG at the final stages (44 DAA) provided greater total antioxidant activity, despite the lower ascorbate peroxidase activity. The application of $\mathrm{GA}_{3}$ pre-harvest increases the firmness and diameter of the cashew peduncles, and the treatment with AVG increases the total antioxidant activity of the peduncles.
\end{abstract}

Index terms: Anacardium occidentale, $\mathrm{AVG}, \mathrm{GA}_{3}$, phenolic compounds.

\section{Influência do tratamento pré-colheita com 1-aminoetoxivinilglicina e ácido giberélico na fisiologia e na qualidade de pedúnculos de caju}

Resumo - O objetivo deste trabalho foi avaliar o efeito do tratamento pré-colheita com ácido giberélico $\left(\mathrm{GA}_{3}\right)$ e 1-aminoetoxivinilglicina (AVG) nos atributos de qualidade e fisiológicos de pedúnculos maduros de cajueiro (Anacardium occidentale) 'CCP 76', em diferentes estádios de desenvolvimento. Foram realizadas pulverizações com $180 \mathrm{mg} \mathrm{L}^{-1} \mathrm{GA}_{3}$ e $180 \mathrm{mg} \mathrm{L}^{-1} \mathrm{AVG}$, combinadas e isoladas, aos 34, 40 e 44 dias após a antese (DAA), e os pedúnculos foram colhidos maduros aos 46 DAA para avaliações de variáveis físicas e fisiológicas. $\mathrm{O}$ tratamento com $\mathrm{GA}_{3}$ proporcionou pedúnculos mais firmes e com maior diâmetro apical, mas não influenciou as variáveis fisiológicas atividades das enzimas pectinametilesterase e poligalacturonase da parede celular e grau de peroxidação lipídica das membranas biológicas, nem os atributos físicos massa total (pedúnculo e castanha) e comprimento e largura da castanha. Em estádios iniciais (34 DAA), $\mathrm{GA}_{3}$ aumentou a atividade das enzimas antioxidantes superóxido dismutase e catalase, e, nos finais (40 DAA), promoveu o acúmulo de polifenóis e carotenoides. A aplicação de AVG, ao final do desenvolvimento (44 DAA), proporcionou maior atividade antioxidante, apesar da menor atividade da ascorbato peroxidase. A aplicação de $\mathrm{GA}_{3}$ em pré-colheita promove aumento da firmeza e do diâmetro dos pedúnculos de cajueiro, e o tratamento com AVG aumenta a atividade antioxidante dos pedúnculos.

Termos para indexação: Anacardium occidentale, AVG, $\mathrm{GA}_{3}$, compostos fenólicos.

\section{Introduction}

Cashew (Anacardium occidentale L.) is constituted of a nut (true fruit) and of a fleshy peduncle, also referred to as cashew apple, a non-climacteric pseudofruit, which should be harvested ripe. In Brazil, its production is concentrated in the dry season, from August to December, in the Northeastern region.

Although the nut is the most relevant economically, the peduncle is a rich source of vitamin C, carotenoids, and phenolic compounds, which contribute to its high antioxidant capacity (Lopes et al., 2012). However,
Pesq. agropec. bras., Brasília, v.53, n.6, p.684-692, June 2018

DOI: 10.1590/S0100-204X2018000600004 (c) BY This is an open-access article distributed under the Creative Commons Attribution 4.0 International License 
the short postharvest life of 48 hours, at ambient condition $\left(24^{\circ} \mathrm{C}\right)$, represents a major obstacle to the marketing of cashew apples, as the accentuated loss of firmness compromises both their handling and quality (Moura et al., 2010).

In order to extend the postharvest storage period of cashew apples, several technologies have been adopted, such as refrigeration (Moura et al., 2010), gamma radiation (Souza et al., 2009), and postharvest calcium application (Figueiredo et al., 2007). At preharvest, plant growth regulator treatments have been used aiming to delay ripening and preserve postharvest fruit quality, considering that regulators affect plant growth and development, acting as messengers on a broad spectrum of metabolic processes (Marzouk \& Kassem, 2011). Different doses of 1-aminoethoxyvinylglycine (AVG) or gibberellic acid $\left(\mathrm{GA}_{3}\right)$, for example, have been applied to peach, banana, and plum, in different developmental stages, to extend their postharvest storage life (Amarante et al., 2005; Huang et al., 2014; Steffens et al., 2011). When applied at preharvest, $\mathrm{GA}_{3}$ significantly influenced the ripening of both climacteric and non-climacteric fruit, including loquat [Eriobotrya japonica (Thunb.) Lindl.], grape (Vitis vinifera $\times$ Vitis labrusca), and sweet cherry [Prunus avium (L.) L.] (Mesejo et al., 2010; Zhang \& Whiting, 2013). In preharvest treatments, AVG, as an inhibitor of ethylene synthesis, resulted in firmer fruit with higher titratable acidity and soluble solids contents, as well as in a lower incidence of physiological disorders (Steffens et al., 2011).

Although several preharvest treatments with growth regulators have been reported for fruit (Amarante et al., 2005; Huang et al., 2014; Mesejo et al., 2010; Steffens et al., 2011; Zhang \& Whiting, 2013), only one was used to evaluate the effects of the preharvest application of growth regulators on cashew cultivars (Souza et al., 2016). In this study, 'CCP 76' and 'BRS 189 ' cashew were treated with $180 \mathrm{mg} \mathrm{L}^{-1} \mathrm{AVG}$ and $\mathrm{GA}_{3}$ at maturation stage 1 , and peduncles were harvested ripe at stage 7 and then stored under refrigeration for 20 days. The obtained results showed that, during the postharvest storage of cashew peduncles, $\mathrm{GA}_{3}$ had a greater effect on 'BRS 189' reducing mass and firmness losses, while the effects of AVG on cashew peduncle physiology and quality were inconsistent.
The objective of this work was to evaluate the effects of the preharvest treatment with $\mathrm{GA}_{3}$ and AVG on the quality and physiological attributes of ripe 'CCP 76' cashew peduncles at different developmental stages.

\section{Materials and Methods}

The study was conducted at the experimental station of Embrapa Agroindústria Tropical, located in Pacajus, in the state of Ceará, Northeastern Brazil (4'11'27"S, $\left.38^{\circ} 29^{\prime} 51^{\prime \prime} \mathrm{W}\right)$. The soil of the experimental area is classified as a Neossolo quartzarênico, i.e., a Typic Quartzipsamment, according to the Brazilian system of soil classification (Santos et al., 2013). Early 'CCP 76 ' cashew trees with 20 years of age were spaced at $6 \times 4 \mathrm{~m}$ in the experimental area, which had an annual average rainfall of $652 \mathrm{~mm}$.

A preliminary preharvest experiment was carried out to evaluate the effects of different AVG and $\mathrm{GA}_{3}$ concentrations $\left(60,120\right.$, and $\left.180 \mathrm{mg} \mathrm{L}^{-1}\right)$ on cashew apple physical attributes. Since the dose of $180 \mathrm{mg} \mathrm{L}^{-1}$ resulted in firmer ripe peduncles, which is one of the main factors limiting the postharvest life of cashew peduncles, $150 \mathrm{mg} \mathrm{g}^{-1} \mathrm{AVG}$ and $100 \mathrm{mg} \mathrm{g}^{-1} \mathrm{GA}_{3}$ of the commercial products ReTain (Valent BioSciences, Libertyville, IL, USA) and ProGibb (Sumitomo Corporation, Tokyo, Japan), respectively, were diluted in water plus surfactant $0.5 \%$ Tween $20(\mathrm{v} / \mathrm{v})$ to a concentration of $180 \mathrm{mg} \mathrm{L}^{-1}$, which was then manually applied with a backpack sprayer onto the canopy of the trees, at an amount enough to flow thoroughly over the entire plant. Two hundred trees were divided into six treatment plots; plots on the same row were separated by at least one tree, and rows of treated trees were separated by an untreated row, in order to avoid drift effects. The experiment was carried out in a completely randomized design, consisting of six treatments with three replicates of 15 fruit each.

The treatments consisted of the applications of 180 mg L $\mathrm{L}^{-1} \mathrm{AVG}$ and $\mathrm{GA}_{3}$ on cashew trees at different developmental stages after anthesis (DAA): $\mathrm{T} 1, \mathrm{GA}_{3}$ at $34 \mathrm{DAA} ; \mathrm{T} 2, \mathrm{GA}_{3}$ at $34 \mathrm{DAA}+\mathrm{AVG}$ at $44 \mathrm{DAA}$; T3, GA 3 at $40 \mathrm{DAA} ; \mathrm{T} 4, \mathrm{GA}_{3}$ at $40 \mathrm{DAA}+\mathrm{AVG}$ at 44 DAA; T5, AVG at 44 DAA; and a control, without $\mathrm{GA}_{3}$ and AVG.

Pesq. agropec. bras., Brasília, v.53, n.6, p.684-692, June 2018 DOI: $10.1590 / \mathrm{S} 0100-204 X 2018000600004$ 
At 46 DAA, ripe orange-colored cashew peduncles at stage 7, according to Lopes et al. (2012), from all treatments, were manually harvested and transported to the laboratory, where they were selected based on color homogeneity (dark-orange peduncle), size, and absence of defects. Cashew peduncles were immediately evaluated for physical attributes and then processed with the RI6720 Walita domestic centrifuge (Philips do Brasil Ltda - Divisão Walita, Varginha, $\mathrm{MG}$, Brazil). The pulp was stored at $-18^{\circ} \mathrm{C}$, until analyzes for variables associated with firmness and antioxidant metabolism.

Total mass (nut with peduncle) was determined using the Mark 3100 analytical scale (Bel Engineering, Monza, Italy) and was expressed in grams. Peduncle and nut sizes were measured with the Ultra-Cal Mark III digital caliper (Sylvac/Fowler, Crissier, Switzerland), and results were expressed in millimeters.

Firmness was evaluated five times on opposite sides of each peduncle with the Magness-Taylor FT-011 manual penetrometer (Instron, Norwood, MA, USA) using an $8-\mathrm{mm}$ diameter cylindrical flat-tipped steel plunger, and results were expressed in Newton.

Biological membrane integrity was estimated by the degree of lipid peroxidation, which was determined by the formation of malondialdehyde (MDA), based on the method described by Zhu et al. (2008). Absorbance at $532 \mathrm{~nm}$ was measured, corrected for unspecific turbidity by subtracting from absorbance at $600 \mathrm{~nm}$, and MDA content - expressed as nmol MDA g-1 fresh weight $(\mathrm{FW})$ - was calculated using an extinction coefficient of $155 \mathrm{nmol} \mathrm{cm}^{-1}$.

Cell wall integrity was evaluated through the specific activities of cell wall hydrolases. Polygalacturonase (PG, E.C. 3.2.1.15) activity was assessed in 12-g samples homogenized with $25 \mathrm{~mL}$ ice-cold water. The homogenate was filtered through Whatman No. 1 filter paper and centrifuged at $3,248 \mathrm{~g}$, for $10 \mathrm{~min}$, at $4^{\circ} \mathrm{C}$; the precipitate was suspended in $10 \mathrm{~mL}$ distilled water and centrifuged as before. The reaction mixture was incubated for 3 hours at $30^{\circ} \mathrm{C}$, followed by a boiling water bath to stop the reaction. The liberated reducing groups were determined (Pressey, 1986), and results were expressed as unit of enzyme activity (UA) $\mathrm{mg}^{-1}$ protein.
For the pectin methylesterase (PME, EC 3.1.1.11) assay, $5 \mathrm{~g}$ pulp were extracted by homogenization with $20 \mathrm{~mL}$ cold $\mathrm{NaCl}\left(0.2 \mathrm{~mol} \mathrm{~L}^{-1}\right)$ and then filtered through Whatman No. 1 filter paper; the filtrate was used as enzyme extract (Hagerman \& Austin, 1986). Enzyme activity was measured in $5 \mathrm{~mL}$ of the extract plus $30 \mathrm{~mL}$ of $1 \%$ citrus pectin substrate in $0.2 \mathrm{~mol}$ $\mathrm{L}^{-1} \mathrm{NaCl}(\mathrm{pH} 7.0)$ titrated with $0.01 \mathrm{~N} \mathrm{NaOH}$. One unit of activity was defined as the amount of enzyme capable of removing a methyl group from pectin and was expressed as UA $\mathrm{mg}^{-1}$ protein.

Total protein content was obtained according to Bradford (1976) using bovine serum albumin as standard and was expressed as $\mathrm{mg} \mathrm{g}^{-1} \mathrm{FW}$. Protein content was used to calculate the specific enzyme activity.

To determine bioactive antioxidant compounds and total antioxidant activity (anthocyanins and yellow flavonoids), $1 \mathrm{~g}$ pulp was extracted with a $95 \%$ ethanol:1.5 N HCl (85:15) solution, vortexed for 2 $\mathrm{min}$, and then brought to $50 \mathrm{~mL}$ with the extracting solution. The mixture was protected from the light, refrigerated at $4^{\circ} \mathrm{C}$ for 12 hours, and filtered in Whatman No. 1 paper. The absorbance of the filtrate was measured at $535 \mathrm{~nm}$ for total anthocyanin content, using an absorption coefficient of $98.2 \mathrm{~mol} \mathrm{~cm}^{-1}$, and at $374 \mathrm{~nm}$ for total yellow flavonoid content, using an absorption coefficient of $76.6 \mathrm{~mol} \mathrm{~cm}^{-1}$; both results were expressed as mg $100 \mathrm{~g}^{-1} \mathrm{FW}$.

Total phenolics were determined with a colorimetric assay using the Folin-Ciocalteu reagent according to Obanda et al. (1997), while extracts were prepared as in Larrauri et al. (1997). Samples of $3 \mathrm{~g}$ each were homogenized in $4 \mathrm{~mL}$ methanol $(50 \%)$ and allowed to stand in the dark, at room conditions, for 1 hour, before centrifugation at $4,000 \mathrm{~g}$, for $30 \mathrm{~min}$, at $4^{\circ} \mathrm{C}$. The supernatant was collected, and the precipitate was extracted with $4 \mathrm{~mL}$ acetone $(70 \%)$ under conditions similar to those previously described. After centrifugation, supernatants were joined and total volume was completed to $10 \mathrm{~mL}$ with distilled water. Extracts of $100 \mu \mathrm{L}$ were added to $100 \mu \mathrm{L}$ FolinCiocalteu reagent, $1 \mathrm{~mL} \mathrm{Na} \mathrm{CO}_{3}(20 \%)$, and $1 \mu \mathrm{L}$ distilled water, and were allowed to stand for $30 \mathrm{~min}$, in the dark. Absorbance was measured at $700 \mathrm{~nm}$, and results were expressed as gallic acid equivalents $\mathrm{mg}$ $100 \mathrm{~g}^{-1} \mathrm{FW}$. 
Total vitamin $\mathrm{C}$ was determined by titration with a $0.02 \%$ 2,6-dichloro-indophenol solution (Strohecker et al., 1967). One gram of pulp was diluted to $50 \mathrm{~mL}$ $0.5 \%$ oxalic acid and homogenized, and $2 \mathrm{~mL}$ of this solution were diluted to $50 \mathrm{~mL}$ with distilled water and then titrated. Results were expressed as $\mathrm{mg} 100 \mathrm{~g}^{-1} \mathrm{FW}$.

Total carotenoids were extracted and determined as described by Higby (1962). Five grams of pulp were homogenized in $30 \mathrm{~mL}$ isopropyl alcohol and $10 \mathrm{~mL}$ hexane. The content was transferred to a separation funnel of $125 \mathrm{~mL}$ completed with distilled water, and it was let to rest for 30-min periods followed by subsequent filtrations for thrice. Absorbance was measured at $450 \mathrm{~nm}$, and results were expressed as mg $100 \mathrm{~g}^{-1} \mathrm{FW}$.

Total antioxidant activity (TAA) was determined using the 2,2-azino-bis (3-ethylbenzthiazoline-6sulfonic acid) radical cation method according to Re et al. (1999). Before the colorimetric assay, the samples were subjected to extraction in $50 \%$ methanol and $70 \%$ acetone as described by Larrauri et al. (1997). Once the radical was formed, the reaction was started by adding $30 \mu \mathrm{L}$ extract in $3 \mathrm{~mL}$ radical solution, absorbance was measured at $734 \mathrm{~nm}$ after $6 \mathrm{~min}$, and the decrease in absorption was used to calculate TAA. A calibration curve was prepared, and different Trolox concentrations (standard Trolox solutions ranging from 100 to $2,000 \mu \mathrm{mol} \mathrm{L}^{-1}$ ) were also evaluated against the radical. Antioxidant activity was expressed as Trolox equivalent antioxidant capacity (TEAC), i.e., $\mu \mathrm{mol}$ TEAC $\mathrm{g}^{-1} \mathrm{FW}$.

The specific activity of antioxidant enzymes was also assessed. The extracts for antioxidant enzyme activity were prepared as in Yang et al. (2008). One gram of pulp was homogenized during 5 min with 10 $\mathrm{mL}$ phosphate buffer $\left(0.1 \mathrm{~mol} \mathrm{~L}^{-1}, \mathrm{pH} 7\right)$ containing $0.1 \mathrm{mmol} \mathrm{L}^{-1}$ ethylenediaminetetraacetic acid, filtered through Whatman No. 1 paper, and let to rest for 1 hour, prior to centrifugation at $12,000 \mathrm{~g}$, for $15 \mathrm{~min}$, at $4^{\circ} \mathrm{C}$. The supernatant was then collected and used as enzyme extract.

Superoxide dismutase (SOD, EC 1.15.1.1) activity was determined according to Giannopolitis \& Ries (1977), based on the inhibition of the photochemical reduction of nitroblue tetrazolium chloride (NBT). Absorbance was measured at $560 \mathrm{~nm}$, and one unit of SOD activity was defined as the amount of enzyme required to cause a $50 \%$ reduction in the NBT photoreduction rate; results were expressed as UA $\mathrm{mg}^{-1}$ protein.

Catalase (CAT, EC 1.11.1.6) activity was measured using the method described by Beers \& Sizer (1952). The reaction was started by adding the enzyme extract, and the decrease in $\mathrm{H}_{2} \mathrm{O}_{2}$ was monitored through absorbance at $240 \mathrm{~nm}$ and quantified by its molar extinction coefficient $\left(36 \mathrm{~mol} \mathrm{~L}^{-1} \mathrm{~cm}^{-1}\right)$. Results were expressed as $\mu \mathrm{mol} \mathrm{H}_{2} \mathrm{O}_{2} \mathrm{~min}^{-1} \mathrm{mg}^{-1}$ protein.

Ascorbate peroxidase (APX, EC 1.11.1.1) activity was assessed according to Nakano \& Asada (1981). The reaction was started by adding ascorbic acid, and ascorbate oxidation was measured by recording the absorbance readings at $290 \mathrm{~nm}$. The APX activity was measured using the molar extinction coefficient for ascorbate $\left(\varepsilon 290=2.8 \mathrm{mmol} \mathrm{L}^{-1} \mathrm{~cm}^{-1}\right)$, and results were expressed in $\mu \mathrm{mol} \mathrm{H}_{2} \mathrm{O}_{2} \mathrm{~min}^{-1} \mathrm{mg}^{-1}$ protein.

Data were subjected to the analysis of variance using the Sisvar computer software, version 5.3 (Ferreira, 2011), and the averages were compared by Tukey's test, at $5 \%$ probability.

\section{Results and Discussion}

Combined or isolated $\mathrm{GA}_{3}$ and AVG preharvest treatments did not significantly affect some of the evaluated physical attributes of 'CCP 76' cashew, such as total cashew (nut and peduncle) mass, peduncle mass, peduncle length, and nut length (Table 1). However, nut mass and width were lower in T2, T3, and T4, when compared with the control, which presented mass of $9.34 \mathrm{~g}$ and width of $26.4 \mathrm{~mm}$. T1 significantly increased the peduncle apical diameter $(51.24 \mathrm{~mm})$ in comparison with the control $(45.9 \mathrm{~mm})$, which did not differ from the other treatments. It was reported that the active gibberellins $\mathrm{GA}_{1}$ and $\mathrm{GA}_{3}$ play an essential role in the growth regulating expansion of recently divided cells, influencing fruit size (Jong et al., 2009; Zhang \& Whiting, 2013). This could explain the results found for the T1 treatment at an earlier developmental stage, which induced an increase in the peduncle apical diameter. Other fruits also had their size affected by treatments with gibberellins. Rufini et al. (2008), for example, observed that $20 \mathrm{mg} \mathrm{L}^{-1} \mathrm{GA}_{3}$ promoted an increase in 'Ponkan' mandarin (Citrus 
reticulata $\mathrm{Blanco}$ ) diameter, while $\mathrm{GA}_{3}$ concentrations from 250 to $1,000 \mathrm{mg} \mathrm{L}^{-1}$ led to proportional increases in 'Gefner' atemoya (Annona cherimola Miller $\mathrm{x}$ Annona squamosa L.) size (Pereira et al., 2014).

Cashew peduncles subjected to $\mathrm{GA}_{3}$ treatments (T1-T4) were significantly firmer, over $20 \%$, than the control, whose value was $16.9 \mathrm{~N}$, which did not differ from that of T5 (Table 2). Firmness is an important quality attribute of fresh fruits and may be affected by different factors, such as turgor, starch content, cell wall enzymes, and integrity of biological membranes (Jacomino et al., 2010). Previous studies with strawberry (Fragaria x ananassa Duch.) and Chilean strawberry [Fragaria chiloensis (L.) Mill.], which are non-climacteric fruit, subjected to exogenous $\mathrm{GA}_{3}$ and abscisic acid treatments, resulted in increased firmness through the activation of the expression of the FaXTH1 and FaXTH2 genes (Opazo et al., 2013; Nardi et al., 2014 ). Ferri et al. (2002) proposed that the effect of gibberellin on the maintenance of fruit firmness could be related to a reduction in the production of ethylene, a key hormone responsible for the ripening of climacteric fruits and, according to Steffens et al. (2009), also of non-climacteric fruits, as observed for cashew apple in the present study.

The lipid peroxidation degree of 'CCP 76' peduncles was not significantly influenced by the $\mathrm{GA}_{3}$ and $\mathrm{AVG}$ treatments (Table 2). However, this variable may be an indicator of biological membrane integrity, which affects firmness. Moreover, the activities of the cellwall hydrolases PME and PG were also not influenced by growth regulators in the peduncle. This shows that the effects of $\mathrm{GA}_{3}$ in the T1-T4 treatments on cashew peduncle firmness may not be associated with tissue disintegration; however, it may be explained by other factors such as turgor control. Souza et al. (2016) reported that $\mathrm{GA}_{3}$ positively affected 'BRS 189' cashew peduncles, which showed, besides lower loss of mass and firmness, a better visual appearance and

Table 1. Mean values of physical variables of 'CCP 76' cashew (Anacardium occidentale) nut and peduncles treated with $180 \mathrm{mg} \mathrm{L}^{-1}$ gibberellic acid $\left(\mathrm{GA}_{3}\right)$ and $180 \mathrm{mg} \mathrm{L}^{-1}$ aminoethoxyvinylglycine (AVG), isolated or combined, at different days after anthesis (DAA) ${ }^{(1)}$.

\begin{tabular}{|c|c|c|c|c|c|c|c|}
\hline Treatment & $\begin{array}{c}\text { Total mass } \\
(\mathrm{g})\end{array}$ & $\begin{array}{c}\text { Nut mass } \\
(\mathrm{g})\end{array}$ & $\begin{array}{l}\text { Nut length } \\
\text { (mm) }\end{array}$ & $\begin{array}{l}\text { Nut width } \\
\text { (mm) }\end{array}$ & $\begin{array}{l}\text { Peduncle mass } \\
(\mathrm{g})\end{array}$ & $\begin{array}{l}\text { Peduncle apical } \\
\text { diameter }(\mathrm{mm})\end{array}$ & $\begin{array}{c}\text { Peduncle } \\
\text { length }(\mathrm{mm})\end{array}$ \\
\hline Control & $135.77 \mathrm{a}$ & $9.34 \mathrm{a}$ & $33.75 \mathrm{a}$ & $20.49 a$ & $126.43 a$ & $45.98 b$ & $64.38 \mathrm{a}$ \\
\hline $\mathrm{T} 1-\mathrm{GA}_{3}$ at $34 \mathrm{DAA}$ & $131.93 \mathrm{a}$ & $8.59 \mathrm{ab}$ & $33.78 \mathrm{a}$ & $19.53 \mathrm{ab}$ & $123.34 \mathrm{a}$ & $51.24 \mathrm{a}$ & $61.52 \mathrm{a}$ \\
\hline $\mathrm{T} 2-\mathrm{GA}_{3}+\mathrm{AVG}$ at $34 \mathrm{DAA}$ & $131.12 \mathrm{a}$ & $7.90 \mathrm{~b}$ & $33.55 \mathrm{a}$ & $19.21 b$ & $123.22 \mathrm{a}$ & $48.25 \mathrm{ab}$ & $64.31 \mathrm{a}$ \\
\hline $\mathrm{T} 3-\mathrm{GA}_{3}$ at $40 \mathrm{DAA}$ & $136.59 \mathrm{a}$ & $8.33 b$ & $33.96 \mathrm{a}$ & $19.31 b$ & $128.26 \mathrm{a}$ & $49.02 \mathrm{ab}$ & $63.56 \mathrm{a}$ \\
\hline $\mathrm{T} 4-\mathrm{GA}_{3}+\mathrm{AVG}$ at $40 \mathrm{DAA}$ & $127.90 \mathrm{a}$ & $8.23 b$ & $33.75 \mathrm{a}$ & $19.26 b$ & $119.67 \mathrm{a}$ & $47.98 \mathrm{ab}$ & $60.94 a$ \\
\hline T5 - AVG at 44 DAA & $122.77 \mathrm{a}$ & $8.58 \mathrm{ab}$ & $34.20 \mathrm{a}$ & $19.67 \mathrm{ab}$ & $114.19 \mathrm{a}$ & $47.30 \mathrm{ab}$ & $59.21 \mathrm{a}$ \\
\hline
\end{tabular}

${ }^{(1)}$ Means followed by equal letters, in the columns, do not differ by Tukey's test, at $5 \%$ probability.

Table 2. Firmness and associated variables of 'CCP 76' cashew (Anacardium occidentale) peduncles treated with $180 \mathrm{mg} \mathrm{L}^{-1}$ gibberellic acid $\left(\mathrm{GA}_{3}\right)$ and $180 \mathrm{mg} \mathrm{L}^{-1}$ aminoethoxyvinylglycine (AVG), isolated or combined, at different days after anthesis $(\mathrm{DAA})^{(1)}$.

\begin{tabular}{|c|c|c|c|c|}
\hline Treatment & $\begin{array}{l}\text { Firmness } \\
(\mathrm{N})\end{array}$ & $\begin{array}{l}\text { Lipid peroxidation } \\
\left(\mathrm{nmol} \mathrm{g}^{-1}\right)\end{array}$ & $\begin{array}{c}\text { PME activity } \\
\text { (UA } \mathrm{mg}^{-1} \mathrm{~min}^{-1} \text { protein) }\end{array}$ & $\begin{array}{c}\text { PG activity } \\
\text { (UA mg }{ }^{-1} \mathrm{~min}^{-1} \text { protein) }\end{array}$ \\
\hline Control & $16.92 b$ & $36.24 a$ & $1657.43 a$ & $7.80 \mathrm{a}$ \\
\hline $\mathrm{T} 1-\mathrm{GA}_{3}$ at $34 \mathrm{DAA}$ & $20.78 \mathrm{a}$ & $76.20 \mathrm{a}$ & $2438.31 \mathrm{a}$ & $11.01 \mathrm{a}$ \\
\hline $\mathrm{T} 2-\mathrm{GA}_{3}+\mathrm{AVG}$ at $34 \mathrm{DAA}$ & $20.93 a$ & $57.37 \mathrm{a}$ & $2458.72 \mathrm{a}$ & $6.09 \mathrm{a}$ \\
\hline $\mathrm{T} 3-\mathrm{GA}_{3}$ at $40 \mathrm{DAA}$ & $20.63 a$ & $45.67 \mathrm{a}$ & $2521.94 a$ & $6.52 \mathrm{a}$ \\
\hline $\mathrm{T} 4-\mathrm{GA}_{3}+\mathrm{AVG}$ at $40 \mathrm{DAA}$ & $20.37 \mathrm{a}$ & $42.72 \mathrm{a}$ & $2042.48 \mathrm{a}$ & $7.06 \mathrm{a}$ \\
\hline T5 - AVG at 44 DAA & $18.75 \mathrm{ab}$ & $73.52 \mathrm{a}$ & $2464.22 \mathrm{a}$ & $8.97 \mathrm{a}$ \\
\hline
\end{tabular}

${ }^{(1)}$ Means followed by equal letters, in the columns, do not differ by Tukey’s test, at 5\% probability. PME, pectin methylesterase; and PG, polygalacturonase. 
lower cell-wall hydrolase PME activity, during 20 days under refrigerated storage.

The effects of AVG and $\mathrm{GA}_{3}$ on the antioxidant compound contents and total antioxidant activity of 'CCP 76' peduncles varied (Table 3). Anthocyanins, yellow flavonoids, and vitamin $\mathrm{C}$ contents did not differ between the AVG and $\mathrm{GA}_{3}$ treatments and the control, which presented contents of $0.03,0.31$, and $319.41 \mathrm{mg}$ $100 \mathrm{~g}^{-1} \mathrm{FW}$, respectively. However, the T1, T2, T3, and T5 treatments resulted in significantly greater total polyphenol contents; T3 presented the highest value of $224.19 \mathrm{~g}^{-1} \mathrm{FW}$, which was $>14 \%$ greater than the control and T4. The increase in total phenolics is probably due to the presence of other phenolics than anthocyanin and yellow flavonoids, whose values did not change. Contrasting effects of gibberellin on polyphenols were observed in other fruit, including 'Muscat' grapes (Vitis vinifera L.), in which $100 \mathrm{mg} \mathrm{L}^{-1} \mathrm{GA}_{3}$ induced a reduction in phenolic compounds and total antioxidant activity in the pulp and peel (Tian, 2014), and
'Barhee' date palms (Phoenix dactylifera L.) treated with 50 and $100 \mathrm{mg} \mathrm{L}^{-1} \mathrm{GA}_{3}$, which presented total antioxidant activity $18 \%$ lower than that of the control (Mohamed et al., 2014).

Total carotenoid content in peduncles was higher $\left(0.21 \mathrm{mg} 100 \mathrm{~g}^{-1} \mathrm{FW}\right)$ in $\mathrm{T} 3$ and lower $(0.13 \mathrm{mg} 100$ $\left.\mathrm{g}^{-1} \mathrm{FW}\right)$ in $\mathrm{T} 4$ and $\mathrm{T} 5$, which showed similar results. Regarding total antioxidant activity, only $\mathrm{T} 5$ presented a value higher $\left(20.53 \mu \mathrm{mol}\right.$ TEAC g $\left.{ }^{-1} \mathrm{FW}\right)$ than that of the control, with $12.48 \mu$ mol TEAC $\mathrm{g}^{-1} \mathrm{FW}$. Lopes et al. (2012) reported that the polyphenol contents of 'CCP 76 ' peduncles reduced during ripening and that they were strongly correlated to total antioxidant activity; however, except for T5, such association could not be evidenced in the present work.

Regarding the activities of antioxidant enzymes (Table 4), SOD activity in the peduncles was higher (916.40 UA $\mathrm{mg}^{-1}$ protein) in $\mathrm{T} 1$, while the control showed a value of $564.14 \mathrm{UA} \mathrm{mg}^{-1}$ protein. CAT activity was also higher $\left(66.13 \mu \mathrm{mol} \mathrm{H}_{2} \mathrm{O}_{2} \mathrm{~min}^{-1} \mathrm{mg}^{-1}\right)$ in the

Table 3. Antioxidant compounds and total antioxidant activity of 'CCP 76' cashew (Anacardium occidentale) peduncles treated with $180 \mathrm{mg} \mathrm{L}^{-1}$ gibberellic acid $\left(\mathrm{GA}_{3}\right)$ and $180 \mathrm{mg} \mathrm{L}^{-1}$ aminoethoxyvinylglycine (AVG), isolated or combined, at different days after anthesis (DAA) ${ }^{(1)}$.

\begin{tabular}{|c|c|c|c|c|c|c|}
\hline Treatment & $\begin{array}{l}\text { Total anthocyanins } \\
\left(\mathrm{mg} 100 \mathrm{~g}^{-1}\right)\end{array}$ & $\begin{array}{c}\text { Yellow flavonoids } \\
\left(\mathrm{mg} 100 \mathrm{~g}^{-1}\right)\end{array}$ & $\begin{array}{l}\text { Total polyphenols } \\
\left(\mathrm{mg} 100 \mathrm{~g}^{-1}\right)\end{array}$ & $\begin{array}{l}\text { Total vitamin } \mathrm{C} \\
\left(\mathrm{mg} 100 \mathrm{~g}^{-1}\right)\end{array}$ & $\begin{array}{l}\text { Total carotenoids } \\
\left(\mathrm{mg} 100 \mathrm{~g}^{-1}\right)\end{array}$ & $\begin{array}{c}\text { Antioxidant activity } \\
\left(\mu \mathrm{mol} \text { TEAC } \mathrm{g}^{-1}\right)\end{array}$ \\
\hline Control & $0.03 \mathrm{a}$ & $0.31 \mathrm{a}$ & $164.67 \mathrm{c}$ & $319.41 \mathrm{a}$ & $0.18 \mathrm{bc}$ & $12.48 \mathrm{~b}$ \\
\hline $\mathrm{T} 1-\mathrm{GA}_{3}$ at $34 \mathrm{DAA}$ & $0.09 \mathrm{a}$ & $0.51 \mathrm{a}$ & $206.34 \mathrm{ab}$ & $322.08 \mathrm{a}$ & $0.18 b c$ & $10.72 b$ \\
\hline $\mathrm{T} 2-\mathrm{GA}_{3}+\mathrm{AVG}$ at $34 \mathrm{DAA}$ & $0.05 \mathrm{a}$ & $0.38 \mathrm{a}$ & $188.69 b$ & $352.01 \mathrm{a}$ & $0.19 b$ & $9.64 b$ \\
\hline $\mathrm{T} 3-\mathrm{GA}_{3}$ at $40 \mathrm{DAA}$ & $0.03 \mathrm{a}$ & $0.41 \mathrm{a}$ & $224.19 \mathrm{a}$ & $362.23 \mathrm{a}$ & $0.21 \mathrm{a}$ & $16.51 \mathrm{ab}$ \\
\hline $\mathrm{T} 4-\mathrm{GA}_{3}+\mathrm{AVG}$ at $40 \mathrm{DAA}$ & $0.04 \mathrm{a}$ & $0.35 \mathrm{a}$ & $161.49 \mathrm{c}$ & $326.31 \mathrm{a}$ & $0.13 \mathrm{c}$ & $15.84 \mathrm{ab}$ \\
\hline T5 - AVG at 44 DAA & $0.03 \mathrm{a}$ & $0.36 \mathrm{a}$ & $199.44 \mathrm{ab}$ & $330.36 \mathrm{a}$ & $0.14 \mathrm{bc}$ & $25.03 \mathrm{a}$ \\
\hline
\end{tabular}

${ }^{(1)}$ Means followed by equal letters, in the columns, do not differ by Tukey's test, at 5\% probability. TEAC, Trolox equivalent antioxidant activity.

Table 4. Activities of antioxidant enzymes of 'CCP 76' cashew (Anacardium occidentale) peduncles treated with $180 \mathrm{mg} \mathrm{L}^{-1}$ gibberellic acid $\left(\mathrm{GA}_{3}\right)$ and $180 \mathrm{mg} \mathrm{L}^{-1}$ aminoethoxyvinylglycine (AVG), isolated or combined, at different days after anthesis $(\mathrm{DAA})^{(1)}$.

\begin{tabular}{lccc}
\hline Treatment & $\begin{array}{c}\text { SOD activity } \\
\left(\mathrm{UA} \mathrm{mg}^{-1} \text { protein }\right)\end{array}$ & $\begin{array}{c}\text { CAT activity } \\
\left(\mu \mathrm{mol} \mathrm{H} \mathrm{O}_{2} \mathrm{mg}^{-1} \mathrm{~min}^{-1} \text { protein }\right)\end{array}$ & $\begin{array}{c}\text { APX activity } \\
\left(\mu \mathrm{mol} \mathrm{H} \mathrm{O}_{2} \mathrm{mg}^{-1} \mathrm{~min}^{-1} \mathrm{protein}\right)\end{array}$ \\
\hline Control & $564.14 \mathrm{~d}$ & $46.82 \mathrm{ab}$ & $0.15 \mathrm{a}$ \\
$\mathrm{T} 1-\mathrm{GA}_{3}$ at 34 DAA & $916.40 \mathrm{a}$ & $66.13 \mathrm{a}$ & $0.16 \mathrm{a}$ \\
$\mathrm{T} 2-\mathrm{GA}_{3}+$ AVG at 34 DAA & $565.02 \mathrm{~d}$ & $36.27 \mathrm{~b}$ & $0.12 \mathrm{ab}$ \\
$\mathrm{T} 3-\mathrm{GA}_{3}$ at 40 DAA & $574.76 \mathrm{~d}$ & $40.15 \mathrm{~b}$ & $0.18 \mathrm{a}$ \\
$\mathrm{T} 4-\mathrm{GA}_{3}+$ AVG at 40 DAA & $647.61 \mathrm{c}$ & $36.70 \mathrm{~b}$ & $0.16 \mathrm{a}$ \\
$\mathrm{T} 5-\mathrm{AVG}$ at 44 DAA & $746.07 \mathrm{~b}$ & $48.67 \mathrm{ab}$ & $0.07 \mathrm{~b}$ \\
\hline
\end{tabular}

${ }^{(1)}$ Means followed by equal letters, in the columns, do not differ by Tukey's test, at 5\% probability. SOD, superoxide dismutase; CAT, catalase; and APX, ascorbate peroxidase. 
peduncles subjected to T1, and APX activity was lower $\left(0.07 \mu \mathrm{mol} \mathrm{H}_{2} \mathrm{O}_{2} \mathrm{~min}^{-1} \mathrm{mg}^{-1}\right.$ protein $)$ in those treated with T5, when compared with the control, which showed a value of $0.15 \mu \mathrm{mol} \mathrm{H}_{2} \mathrm{O}_{2} \mathrm{~min}^{-1} \mathrm{mg}^{-1}$ protein. Ding et al. (2015) pointed out that $0.20 \mathrm{mmol} \mathrm{L}^{-1}$ gibberellins induced a reduction in lipid peroxidation degree and an increase in SOD activity, during 28 days of cold storage of cherry tomato (Solanum lycopersicum L.). Saeed et al. (2014) also found that the application of exogenous $\mathrm{GA}_{3}$ enhanced SOD activity during the storage of cut gladiolus flower (Gladiolus hortulanus L.H.Bailey).

The coordinated action of enzymes and nonenzymatic antioxidants is necessary to neutralize reactive oxygen species and, therefore, protect biological membranes from oxidative damage induced by adverse environmental conditions or by developmental processes, as ripening. This is an indicative that a greater antioxidant potential may result in the improvement of postharvest fruit quality.

\section{Conclusions}

1. The gibberellic acid $\left(\mathrm{GA}_{3}\right)$ preharvest treatment of 'CCP 76' cashew (Anacardium occidentale) peduncles at 34 days after anthesis (DAA) increases ripe peduncle apical diameter without any negative effects on nut mass and size, enhances fruit firmness and total polyphenol content, and induces higher activities of the antioxidant enzymes superoxide dismutase and catalase.

2. At $40 \mathrm{DAA}$, the treatment with $\mathrm{GA}_{3}$ increases total carotenoid and polyphenol contents of ripe 'CCP 76 ' cashew peduncles.

3. The aminoethoxyvinylglycine preharvest treatment of 'CCP 76' cashew peduncles at 44 DAA induces a greater total antioxidant activity in the ripe peduncles, despite the lowest ascorbate peroxidase enzymatic activity.

\section{Acknowledgments}

To Embrapa Agroindústria Tropical and Instituto Nacional de Ciência e Tecnologia de Frutos Tropicais (INCT), for financial support; and to Coordenação de Aperfeiçoamento de Pessoal de Nível Superior (Capes) and to Fundação Cearense de Apoio ao Desenvolvimento Científico e Tecnológico (Funcap), for scholarships granted.

\section{References}

AMARANTE, C.V.T. do; DREHMER, A.M.F.; SOUZA, F. de; FRANCESCATTO, P. A pulverização pré-colheita com ácido giberélico $\left(\mathrm{GA}_{3}\right)$ e aminoetoxivinilglicina (AVG) retarda a maturação e reduz as perdas de frutos na cultura do pessegueiro. Revista Brasileira de Fruticultura, v.27, p.1-5, 2005. DOI: $10.1590 / \mathrm{S} 0100-29452005000100003$.

BEERS JR., R.F.; SIZER, I.W. A spectrophotometric method for measuring the breakdown of hydrogen peroxide by catalase. Journal of Biological Chemistry, v.195, p.133-140, 1952.

BRADFORD, M.M. A rapid and sensitive method for the quantitation of microgram quantities of protein utilizing the principle of protein-dye binding. Analytical Biochemistry, v.72, p.248-254, 1976. DOI: 10.1016/0003-2697(76)90527-3.

DING, Y.; SHENG, J.; LI, S.; NIE, Y.; ZHAO, J.; ZHU, Z.; WANG, Z.; TANG, X. The role of gibberellins in the mitigation of chilling injury in cherry tomato (Solanum lycopersicum L.) fruit. Postharvest Biology and Technology, v.101, p.88-95, 2015. DOI: 10.1016/j.postharvbio.2014.12.001.

FERREIRA, D.F. Sisvar: a computer statistical analysis system. Ciência e Agrotecnologia, v.35, p.1039-1042, 2011. DOI: $10.1590 /$ S1413-70542011000600001.

FERRI, V.C.; RINALDI, M.M.; DANIELI, R.; LUCHETTA, L.; ROMBALDI, C.V. Controle da maturação de caquis 'Fuyu', com uso de aminoethoxivinilglicina e ácido giberélico. Revista Brasileira de Fruticultura, v.24, p.344-347, 2002. DOI: $10.1590 / \mathrm{S} 0100-29452002000200014$.

FIGUEIREDO, R.W. de; LAJOLO, F.M.; ALVES, R.E.; FILGUEIRAS, H.A.C.; MAIA, G.A.; SOUSA, P.H.M. de. Qualidade de pedúnculos de caju submetidos à aplicação pós-colheita de cálcio e armazenados sob refrigeração. Pesquisa Agropecuária Brasileira, v.42, p.475-482, 2007. DOI: 10.1590/S0100-204X2007000400004.

GIANNOPOLITIS, C.N.; RIES, S.K. Superoxide dismutases I. Occurrence in higher plants. Plant Physiology, v.59, p.309-314, 1977. DOI: $10.1104 /$ pp.59.2.309.

HAGERMAN, A.E.; AUSTIN, P.J. Continuous spectrophotometric assay for plant pectin methyl esterase. Journal of Agricultural and Food Chemistry, v.34, p.440-444, 1986. DOI: $10.1021 /$ jf00069a015.

HIGBY, W.K. A simplified method for determination of some aspects of the carotenoid distribution in natural and carotenefortified orange juice. Journal of Food Science, v.27, p.42-49, 1962. DOI: 10.1111/j.1365-2621.1962.tb00055.x.

HUANG, H.; JING, G.; WANG, H.; DUAN, X.; QU, H., JIANG, $Y$. The combined effects of phenylurea and gibberellins on quality maintenance and shelf life extension of banana fruit during storage. Scientia Horticulturae, v.167, p.36-42, 2014. DOI: 10.1016/j.scienta.2013.12.028.

JACOMINO, A.P.; GALLON, C.Z.; DIAS, I.S.; PEREIRA, W.S.P. Characterization and occurrence of early softening disorder in 
'Golden' papaya fruits. Revista Brasileira de Fruticultura, v.32, p.1261-1266, 2010. DOI: 10.1590/S0100-29452010005000126.

JONG, M. de; MARIANI, C.; VRIEZEN, W.H. The role of auxin and gibberellin in tomato fruit set. Journal of Experimental Botany, v.60, p.1523-1532, 2009. DOI: 10.1093/jxb/erp094.

LARRAURI, J.A.; RUPÉREZ, P.; SAURA-CALIXTO, F. Effect of drying temperature on the stability of polyphenols and antioxidant activity of red grape pomace peels. Journal of Agricultural and Food Chemistry, v.45, p.1390-1393, 1997. DOI: $10.1021 / \mathrm{jf} 960282 \mathrm{f}$.

LOPES, M.M. de A.; MIRANDA, M.R.A. de; MOURA, C.F.H.; ENÉAS FILHO, J. Bioactive compounds and total antioxidant capacity of cashew apples (Anacardium occidentale L.) during the ripening of early dwarf cashew clones. Ciência e Agrotecnologia, v.36, p.325-332, 2012. DOI: 10.1590/S1413-70542012000300008.

MARZOUK, H.A.; KASSEM, H.A. Improving yield, quality, and shelf life of Thompson seedless grapevine by preharvest foliar applications. Scientia Horticulturae, v.130, p.425-430, 2011. DOI: 10.1016/j.scienta.2011.07.013.

MESEJO, C.; REIG, C.; MARTÍNEZ-FUENTES, A.; AGUSTÍ, M. Parthenocarpic fruit production in loquat (Eriobotrya japonica Lindl.) by using gibberellic acid. Scientia Horticulturae, v.126, p.37-41, 2010. DOI: 10.1016/j.scienta.2010.06.009.

MOHAMED, S.A.; AWAD, M.A.; AL-QURASHI, A.D. Antioxidant activity, antioxidant compounds, antioxidant and hydrolytic enzymes activities of 'Barhee' dates at harvest and during storage as affected by pre-harvest spray of some growth regulators. Scientia Horticulturae, v.167, p.91-99, 2014. DOI: 10.1016/j.scienta.2014.01.003.

MOURA, C.F.H.; FIGUEIREDO, R.W. de; ALVES, R.E.; SILVA, E. de O.; ARAÚJO, P.G.L. de; MACIEL, V.T. Aumento da vida útil pós colheita de pedúnculos de cajueiro anão precoce pela redução da temperratura de armazenamento. Ciência e Agrotecnologia, v.34, p.140-145, 2010. DOI: 10.1590/S1413-70542010000100018.

NAKANO, Y.; ASADA, K. Hydrogen peroxide is scavenged by ascorbate-specific peroxidase in spinach chloroplasts. Plant \& Cell Physiology, v.22, p.867-880, 1981. DOI: 10.1093/oxfordjournals.pcp.a076232.

NARDI， C.F.; VILLARREAL， N.M.; OPAZO, M.C.; MARTÍNEZ, G.A.; MOYA-LEÓN, M.A.; CIVELLO, P.M. Expression of FaXTH1 and FaXTH2 genes in strawberry fruit. Cloning of promoter regions and effect of plant growth regulators. Scientia Horticulturae, v.165, p.111-122, 2014. DOI: 10.1016/j.scienta.2013.10.035.

OBANDA, M.; OWUOR, P.O.; TAYLOR, S.J. Flavanol composition and caffeine content of green leaf as quality potential indicators of Kenyan black teas. Journal of the Science of Food and Agriculture, v.74, p.209-215, 1997.

OPAZO, M.C.; LIZANA, R.; PIMENTEL, P.; HERRERA, R.; MOYA-LEÓN, M.A. Changes in the mRNA abundance of $F_{C} X T H 1$ and $F_{C} X T H 2$ promoted by hormonal treatments of Fragaria chiloensis fruit. Postharvest Biology and Technology, v.77, p.28-34, 2013. DOI: 10.1016/j.postharvbio.2012.11.007.
PEREIRA, M.C.T.; SANTOS, R.K.A.; NIETSCHE, S.; MIZOBUTSI, G.P.; SANTOS, E.F. dos. Doses de ácido giberélico na frutificação efetiva e qualidade de frutos de atemoieira 'Gefner'. Revista Brasileira de Fruticultura, v.36, p.184-191, 2014. Edição especial. DOI: 10.1590/S0100-29452014000500022.

PRESSEY, R. Extraction and assay of tomato polygalacturonases. Hortscience, v.21, p.490-492, 1986.

RE, R.; PELLEGRINI, N.; PROTEGGENTE, A.; PANNALA, A.; YANG, M.; RICE-EVANS, C. Antioxidant activity applying an improved ABTS radical cation decolorization assay. Free Radical Biology and Medicine, v.26, p.1231-1237, 1999. DOI: 10.1016/S0891-5849(98)00315-3.

RUFINI, J.C.M.; RAMOS, J.D.; MENDONÇA, V.; ARAÚJO NETO, S.E. de; PIO, L.A.S.; FERREIRA, E.A. Prolongamento do período de colheita da tangerineira 'Ponkan' com aplicação de $\mathrm{GA}_{3}$ e 2,4-D. Ciência e Agrotecnologia, v.32, p.834-839, 2008. DOI: $10.1590 / \mathrm{S} 1413-70542008000300020$.

SAEED, T.; HASSAN, I.; ABBASI, N.A.; JILANI, G. Effect of gibberellic acid on the vase life and oxidative activities in senescing cut gladiolus flowers. Plant Growth Regulators, v.72, p.89-95, 2014. DOI: 10.1007/s10725-013-9839-y.

SANTOS, H.G. dos; JACOMINE, P.K.T.; ANJOS, L.H.C. dos; OLIVEIRA, V.A. de; LUMBRERAS, J.F.; COELHO, M.R.; ALMEIDA, J.A. de; CUNHA, T.J.F.; OLIVEIRA, J.B. de. Sistema brasileiro de classificação de solos. 3.ed. Brasília: Embrapa, 2013. 353p.

SOUZA, A.R.M. de; BRAZACA, S.G.C.; ARTHUR, V.; OLIVEIRA, A.G.C.; SPOTO, M.H.F.; WALDER, J.M.M. Efeito da radiação gama e do armazenamento na qualidade de pedúnculos de caju (Anacardium occidentale L.). Ciência e Agrotecnologia, v.33, p.848-854, 2009. DOI: 10.1590/S1413-70542009000300026.

SOUZA, K.O.; VIANA, R.M.; OLIVEIRA, L. de S.; MOURA, C.F.H.; MIRANDA, M.R.A. Preharvest treatment of growth regulators influences postharvest quality and storage life of cashew apples. Scientia Horticulturae, v.209, p.53-60, 2016. DOI: 10.1016/j.scienta.2016.06.006.

STEFFENS, C.A.; AMARANTE, C.V.T. do; CHECHI, R.; SILVEIRA, J.P.G.; BRACKMANN, A. Aplicação pré-colheita de reguladores vegetais visando retardar a maturação de ameixas 'Laetitia'. Ciência Rural, v.39, p.1369-1373, 2009. DOI: $10.1590 / \mathrm{S} 0103-84782009005000101$.

STEFFENS, C.A.; AMARANTE, C.V.T. do; CHECHI, R.; SILVEIRA, J.P.G.; CORRÊA, T.R. Maturação e qualidade póscolheita de ameixas 'Laetitia' com a aplicação pré-colheita de AVG e $\mathrm{GA}_{3}$. Revista Brasileira de Fruticultura, v.33, p.21-31, 2011. DOI: 10.1590/S0100-29452011000100004.

STROHECKER, R.; MAYOR, F.; HENNIG, H.M. Analisis de vitaminas: métodos comprobados. Madrid: Paz Montalvo, 1967.

TIAN, S.-F. Changes of content and antioxidant activity of phenolic compounds during gibberellin-induced development of seedless Muscat grapevines. Acta Horticulturae, v.1046, p.539548, 2014. DOI: 10.17660/ActaHortic.2014.1046.74. 
YANG, Z.; ZHENG, Y.; CAO, S. Effect of high oxygen atmosphere storage on quality, antioxidant enzymes, and DPPHradical scavenging activity of Chinese bayberry fruit. Journal of Agricultural and Food Chemistry, v.57, p.176-181, 2008. DOI: $10.1021 /$ jf $803007 j$.

ZHANG, C.; WHITING, M. Plant growth regulators improve sweet cherry fruit quality without reducing endocarp growth. Scientia Horticulturae, v.150, p.73-79, 2013. DOI: $10.1016 /$ j.scienta.2012.10.007.

ZHU, S.; SUN, L.; LIU, M.; ZHOU, J. Effect of nitric oxide on reactive oxygen species and antioxidant enzymes in kiwifruit during storage. Journal of the Science of Food and Agriculture, v.88, p.2324-2331, 2008. DOI: 10.1002/jsfa.3353.

Received on March 23, 2017 and accepted on September 27, 2017 